\title{
The Effects of Harmony of Family, Distributive Justice, and Role Ambiguity on Family Member Impediment: The Mediating Role of Relationship Conflict as an Example of Developing Country Turkey
}

\author{
Işıl Pekdemir ${ }^{1}$, Merve Koçoğlu ${ }^{2}$ \& Güney Çetin Gürkan ${ }^{3}$ \\ ${ }^{1}$ Faculty of Business Administration, Istanbul University, Istanbul, Turkey \\ ${ }^{2}$ Departments of Business, Yeditepe University, Istanbul, Turkey \\ ${ }^{3}$ School of Applied Sciences, Trakya University, Edirne, Turkey \\ Correspondence: Merve Koçoğlu, Departments of Business, Yeditepe University, Istanbul, Turkey. E-mail: \\ merve.kocoglu@yeditepe.edu.tr
}

Received: April 23, 2013 Accepted: May 15, 2013 Online Published: June 28, 2013

doi:10.5539/ass.v9n9p131 URL: http://dx.doi.org/10.5539/ass.v9n9p131

\begin{abstract}
This research aims to research into the mediating effect of relationship conflict between perceived harmony of family, perception of distributive justice, role ambiguity of family members and family member impediment in family firms. In order to examine this hypothesis we focused 124 family business in furniture sector in Turkey. Management of family firms have some challenges leading survival problems of the firm. Among the best important problems is family member's impediment while working in their own firm. This study is designed to investigate relationship conflict's mediating role on family member impediment when a family member perceives harmony and distributive justice in their family and finds his role ambiguity. The result of the study stated that relationship conflict is a partial mediator factor the relationship between family member impediment and distributive justice; and family member impediment and role ambiguity and; family member impediment and role ambiguity.
\end{abstract}

Keywords: harmony of the family, perceived distributive justice, role ambiguity, relationship conflict, family member impediment

\section{Introduction}

World business environment is dominated by family firms. Although family can be a factor that strengthens the family business, same family members can also damage the viability of the firm. The principle purpose of this study is to focus on the problem of family member impediment which is general issue of family businesses. In order to point out this problem, this study is applied to furniture sector which has significant problems especially in Turkey. In this sector most of the firms are family owned. This is the main issue that they are not institutionalized which causes so many problems not only in organizational based but also in family based. When we consider the family based problem, one of the most leading one is family member impediment. Perceived family member harmony, distributive justice, role ambiguity, relationship conflicts are the basic elements that affect the family member impediment. In order to contribute the solution of this significant problem we focused those terms.

\section{Literature Review}

\subsection{Harmony of the Family}

The characteristics of the family firms excluding relationships of the family are similar to non-family firms (Lee, 2006). For this reason, researchers are interested in rapports among family members and the problems resulting from these rapports while studying on the family firms. The family relationship directly influences family's business' success. This effect could be positive or negative according to management quality of family business (Olson et al., 2003). Moreover, the family sprit is very important to create a common purpose and to establish a sense of distinction and commitment (Vires, 1993). Strong family member relationships are critical to the accomplishment of a family business. How complicated the financial plans are or how productive the business is not very significant. If family members cannot work together in chime, succession will only be a imagine 
(Amundson, 1997). Hence harmony of the family is esteemed the most life-sustaining resource to enhance in family firms (Lee, 2006). But contrary to this point of view, (Beehr, Drexler \& Faulkner, 1997) any evidence did not find either differences in family harmony between family members and non-family members, however, the findings showed that increasing family harmony would increase the benefits of the family members in business life.

Harmony of the family is referred as "family harmony norms as the degree to which a family perceives standard patterns of family behavior that demonstrate synchronization and integration among family members that can also be indicated through family members" interaction in the family firm (Kidwell, Kellermanns \& Eddleston, 2012). Furthermore, family members take notice of harmony more than non-family firms' members and it is very important for the long term strengths, analyzing the weaknesses and implementing organizational restraints to control the problems (Donnelley, 1964).

The harmony of the family is supported with some family characteristics such as motivation, commitment, loyalty inspiration, willing to work long hours without compensation, high flexibility in work roles (Dyer, 2006; Beehr, Drexler \& Faulkner, 1997). Lee (2006) found that family harmony is positive and significant predictor of organizational commitment, work and life satisfaction. On the contrary, propensity to leave is not foretold notably by family adaptability. (Alpay, Bodur, Yilmaz, Çetinkaya, \& Arikan, 2008) conducted a study about institutionalization process in Turkish family firms and found a positive relationship between harmony of family and the facets of institutionalization such as objectivity, fairness, transparency, formalization, professionalism. In their comprehensive research of effects on family member issues, Kidwell, Kellermanns, Eddleston (2012) pointed out that perceived family harmony norms are noteworthy related to both relationship conflict and family member impediment.

\subsection{Distributive Justice}

The principle of justice needs honest treatment of individuals. In business, the rules used to decide the justice of a situation could be propped up the perceived rights and pulses of the people involved in a given business interactive relation. Justice engages in the problem of what individuals feel that they are due in terms of their rights and performance in the working place (Cavaliere, Mulvaney \& Swerdlow, 2009).

Researchers have conceptualized three types of justice: distributive, procedural and interactional. Distributive justice involves resource allocation and the perceived outcome of exchange. Procedural justice comprises an assessment of the justice of the policies and methods by which an outcome was set downed. Interactional justice refers to justice of the interpersonal behavior employees obtain from organizational policy makers, like managers (Hofer, Knemeyer \& Murphy, 2012; Arin \& Ring, 2010; Chiua, Linb, Sunc \& Hsu, 2007; Fields, Pang \& Chiu, 2000; Fryxel, 1992; Kashyap, Ribeiro, Asare \& Brashear, 2007; Johnson, Holladay \& Quinones, 2009). Distributive justice subscribes employee reactions that belong to specific results, such as pay or job satisfaction, and procedural justice (Bobocel, Agar, Meyer \& Irving, 1998).

The conception of distributive justice originated from social exchange theory that lay streses on the role of equity in shaping successive exchanges (Arnold, Landry, Scheer \& Stan, 2009). Distributive justice focuses on the role of equity, where an individual assesses the fairness of an exchange by comparing the output/input ratio for oneself with others (Haque \& Aslam, 2011; Chiua, Linb, Sunc \& Hsu, 2009; Choi \& Chen, 2004; Haara \& Spell, 2009).

Distributive justice concerns the way resources are allocated (Aquio, 1995; Harris, 2009; Hamilton, 2006; Harvey \& Haines III, 2005). In other words, it can be declared as how honest and distribution of sources is perceived to be (Burrus \& Mattern, 2010; Kumar, Scheer \& Steenkamp, 1995). What's more distributive justice is prevailed when the two ratios are perceived to be same, and is thus comparative in nature (Burrus \& Mattern, 2010). And also it implies to the perceived justice of the tangible results of argue, or debate comprising two or more parties (Blodgett, Donna \& Tax, 1997).

Distributive justice is not constrained to solely concentration about employee rewards or positive outcomes. It is also related to punishment in a honest and simply manner. Hence, distributive justice would be succeeded if the rewards system acts and punishes over and under performers justly (Burrus \& Mattern, 2010). As an example, an individual could set against the pay and benefits received by his or her employee and create a comparison of his or her effort at work with the rewards. As a consequences of this comparison, an individual attempt to change his or her perceptions of inputs or outcomes (Haara \& Spell, 2009). Distributive justice may be subject to associated part be an outcome of individual negotiating processes (Hornung, Glaser \& Rouseau, 2010).

Organizational justice literature suggests that all types of justice of justice can play a particular role in improving 
individual and organizational outcomes (Kwon, Kim, Kang \& Kim, 2008). Many previous studies on distributive justice have demonstrated its direct effects on employee attitudes, suggesting that distributive justice increases job satisfaction, organizational commitment and reduce intention to leave (Arnold, Landry, Scheer \& Stan, 2009; Harvey \& Haines III, 2005; Choil \& Chen, 2007). In general, high levels of distributive justice are typically perceived when outcomes are distributed equally (Cropanzano, 2005). Judge and Colquitt's also claimed that injustice in organization leads to increase stress level of people in organization which also causes conflict not only in organizations but also work-family conflicts (Judge \& Colquitt, 2004). Lack of distributive justice causes increase in conflict in organizations. (Erp, Giebels, Zee \& Duijn, 2011; Whiteman \& Mamen, 2002).

\subsection{Role Ambiguity}

Role is outlined as the set of hopes implemented to the person of a selected status by role senders inside associated on the far side organization's boundaries (GregBon, Wendell \& Aono, 1994). In contrast, ambiguity refers to the relative unpredictability of the outcomes of an individual's behavior (Pearce, 1981). With a simple term, role ambiguity happens when an individual lacks salient, job-related information needed to enact his or her role (Beard, 1996). Furthermore, role ambiguity lacks adequate information both about what his or her tasks are as well as how to accomplish them (Bolat, Bolat \& Yüksel, 2011).

Theoretical framework includes two major types of role ambiguity the first type, is a lack of understanding about what one is expected to do, how to perform one's role, and whose expectations are given priority. The second one is socioemotional ambiguity which is a lack of understanding about how one's performance is evaluated and the consequences of completing one's responsibilities (Doherty \& Hoye, 2011; Sakires, Doherty \& Misener, 2009).

Role ambiguity might occur when the three types of information do not subsist, in other words, at first of all, a person have to cognize what the expectations are and second, a person have to consider something about what activities on his or her part will carry out the role liabilities and the last one a person must know what the result of role performance are to self, others, and the organization so as to perform his or her role (Beard, 1996; Bolat, Bolat \& Yüksel, 2011; Dierdorff \& Rubin, 2007; Ghorpade, Lackritz \& Singh, 2011; Thiagarajan, 2007; Deluga, 1989; Tidd, Mclntyre \& Friedman, 2004). If the reasons of role ambiguity have to be expanded in order to solve problems resulting from it, it can be mentioned that this ambiguity occurs from sufficient information about to do a work. And additionally it is grown out of inadequate coaching, poor communication, or the deliberate retention or distortion of information by a coworker or supervisor. It can be said that well-defined job descriptions and obvious authority relationships can contribute to resolution of ambiguity affairs (Judeh, 2011).

Role ambiguity has detrimental consequences for individuals and organizations (Beard, 1996; Pearce, 1981). In terms of personal and organizational results, role ambiguity has been concerned with the following variables: job satisfaction as and advancement; job-related tension, organizational commitment; autonomy; job involvement, job burnout, work-family conflict and self-rated performance (Peterson \& Smith, 1995; Beard, 1996; GregBon, Wendell \& Aono, 1994; Kalbers \& Cenker, 2008; Pearce, 1981; Netemeyer, Johnston \& Burton 1990; Pandey \& Wright, 2006; Onyemah, 2008). Additionally, role ambiguity leads (indirectly) to turnover because bears upon how to proceed with essential duty result in tension, which enhances turnover intentions (Singh, 1993; Pearce, 1981; Ussahawanitchakit, 2008).

Role ambiguity leads an individual to feel stress, anxiety, or tension receives extra support from research on the physiological effects of unpredictability. The researchers who have inspected the connection between role ambiguity and self-confidence have reached sign of a negative association (Pearce, 1981). A research made by Boles et. al., points out that both role ambiguity and work family conflict have negative effect on organizations especially they decrease job satisfactions of employees (Boles, Wood \& Johnson, 2003). This finding is also clarify by the researchers, they claimed that role ambiguity and role conflict cause an increase in stress which also leads to decrease in job satisfaction and performance (Chonko, 1982; Fatima \& Rehman, 2012; Ram, Khoso, Shah, Abdul \& Chandio, 2011; Onyemah, 2008). According to Tidd's research role ambiguity increases relationship conflict (Tidd, Mclntyre \& Friedman, 2004).

\subsection{Relationship Conflict}

Conflict, in general, is perception of differences, discrepancies and incompatible wishes by the parties involved (Janss, Rispens, Segers \& Jehn, 2012). Task, process and relationship conflicts are commonly explained in related literature (Martínez-Moreno, González-Navarro, Zornoza \& Ripoll, 2009; Kidwell, Kellermanns, Eddleston, 2012). However, in most studies, a distinction is explained between task conflict and relationship conflict (Jehn, 1995; Huang, 2010; Curseu, Boros \& Oerlemans, 2012). Task conflict refers to conflict and judgmental differences about the theme or the topic of the decision (Parayitam, Olson \& Bao, 2010). 
Relationship conflict is defined as an awareness of interpersonal incompatibilities and it includes affective components such as feeling tension, friction, annoyance, animosity (Jehn, 1995; Jehn \& Mannix, 2001), psychosomatic complaints, stress, burnout (Dreu, Dirk \& Marjolein, 2002) and mutual dislikes among colleagues (Chen, 2011) in a work environment. Additionally, relationship conflict causes interpersonal hostility and disturbs harmony (Choi \& Cho, 2011). In related literature task conflict is also referred as substantive conflict (Davis \& Harveston, 2001), relationship conflict is also referred as interpersonal conflict (Dijkstra, 2009; Huang, 2010), affective conflict (Pelled, 1996; Duarte \& Davies, 2003) or emotional conflict (Pelled, Eisenhardt \& Katherine, 1999; Von, Shapiro \& Brett 2004). Process conflict is comparatively a new type and explained as "an awareness of controversies about aspects of how task accomplishment will proceed" (Jehn \& Mannix, 2001). This type of conflict refers to conflicts about the resources and procedures used to complete tasks (Lau \& Cobb, 2010). Conflict types can be analyzed considering positive or negative impacts on performance. Two of the conflict types -task and process- are associated with positive effects but relationship conflict has negative performance outcomes (Kidwell, Kellermanns \& Eddleston, 2012; Lu, Zhou \& Leun, 2011).

The effects of relationship conflict have been studied in various researches and the findings of these researches are significantly worthwhile for both scholars for further studies and the managers interested in providing satisfaction and increasing performance. Relationship conflict is particularly associated with anger, tension (Curseu, Boros \& Oerlemans, 2012), lower level of trust, high turnover intention (Li \& Leung, 2011; Kiran, Richard \& Taylor, 2012), personality differences and dislikes feelings (Martínez-Moreno, González-Navarro, Zornoza \& Ripoll, 2009).

The research of Mills \& Schulz (2009) showed that relationship conflict is negatively related to organizational commitment and job satisfaction. Chen (2011) found a negative effect of relationship conflict on knowledge sharing, but the results also showed that reward and reputation decrease this negative effect.( Lu, Zhou \& Leung 2011) similarly found that knowledge sharing behavior is negatively connected to relationship conflict. They also stated a significant and negative effect of relationship conflict on organizational citizenship behavior.

Regarding the results of the researches analyzing relationship conflict and performance association especially in teams, Jehn \& Mannix (2001) found a significant difference of relationship conflict between the high and low performer groups. Jehn (1995) found that perceived relationship conflict by members of a group decreases job satisfaction, liking of other group members and intent to remain. A recent study by Huang (2012) showed that relationship conflict and team performance have a negatively significant relationship. According to research results which are made by Othman suggested that when the different expectations and unfairness about the employee's performance and reward increase, this will cause increase in conflicting demands which leads to role ambiguity (Othman, 2008). In sum, perceived or experienced relationship conflict has considerably negative effects in teams and groups while working.

Although in previous studies (Li \& Leung, 2011; Kiran, Richard \& Taylor, 2012) it has been suggested that relationship conflict may have various effects on negative attitudes of individuals in work environment, empirical research has rarely been handled to test the effect of relationship conflict on family member issue. In addition, Kellermanns \& Eddleston (2007) studied on conflict types and performance relationship in family firms, but their study did not consist of relationship conflict's effects. But the other study of these two researchers points out that a significant, negative relationship between relationship conflict and firm performance in family firms (Eddleston \& Kellermanns, 2007). The study of Kidwell, Kellermanns \& Eddleston (2012) also found positive relationship between relationship conflict and family member impediment in family firms. So in our study, the relationship conflict will be regarded as detrimental to family firms.

\subsection{Family Member Impediment}

In most of the family owned business, family members work whether they are qualified or not whether they have enough capacity to run the business or not. This is one of the most important issues for the most of family owned business. In other words, family members have a job in family business because they are a family member which is called family impediment (Kidwell, Kellermanns \& Eddleston, 2012). This issue is related to the firm's culture which is defined "as a complex set of values, beliefs, and assumptions and symbols" that defined the way in which a firm conducts it's business (Barney, 1986). Because of the firm's value, some of the family member works for the family firm even they are useless for the business (Kidwell, Kellermanns \& Eddleston, 2012). This causes some problems particularly family member impediment in family business which is especially related to harmony of family, distributive justice, role ambiguity and relationship conflict. Therefore, this study is to focus on the problem of family member impediment which is general issue of family businesses. 


\section{Purpose, Research Model and Hypotheses}

\subsection{Purpose}

The main goal of this study is to explore the mediating effect of relationship conflict between perceived harmony of family, perception of distributive justice, role ambiguity of family members and family member impediment in family firms.

The main objective of this study is to focus on the problem of family member impediment which is general issue of family businesses. In order to state this problem, this study is applied to furniture sector which has significant problems.

According to export statistics, Turkey has taken $30^{\text {th }}$ world's largest furniture exporter from 230 countries (http://www.sanayi.gov.tr/Files/Documents/mobilya-sektoru-raporu-20-06042012151232.pdf, 09.01.2012). As it is understood from this information that furniture sector is important in Turkey.

Most of the researches about family business made about durable goods especially in furniture sector (Altindağ, Zehir \& Acar, 2011; Fletcher, 2009; Miller, Breton-Miller \& Scholnick 2007; Wall \& Preston, 2010). Furniture is produced in accordance with traditional methods with in bench. However, large businesses use automation system while producing the furniture. This causes an important issue especially for small family firms according to sectoral report in 2012. The same report SWOT Analysis shows the problems of furniture sector. Another problem is having lack of organizations in the sector. One of the most substantial issues of this sector points out that the majority businesses in this sector include family businesses. (www.turkishwood.org/TR/Yonlendir.aspx). The results that stated above encourage us to investigate research on family business in furniture sector in Turkey.

\subsection{Research Model}

The research model is designed in accordance with the objective which is stated above. The research model can be seen below.

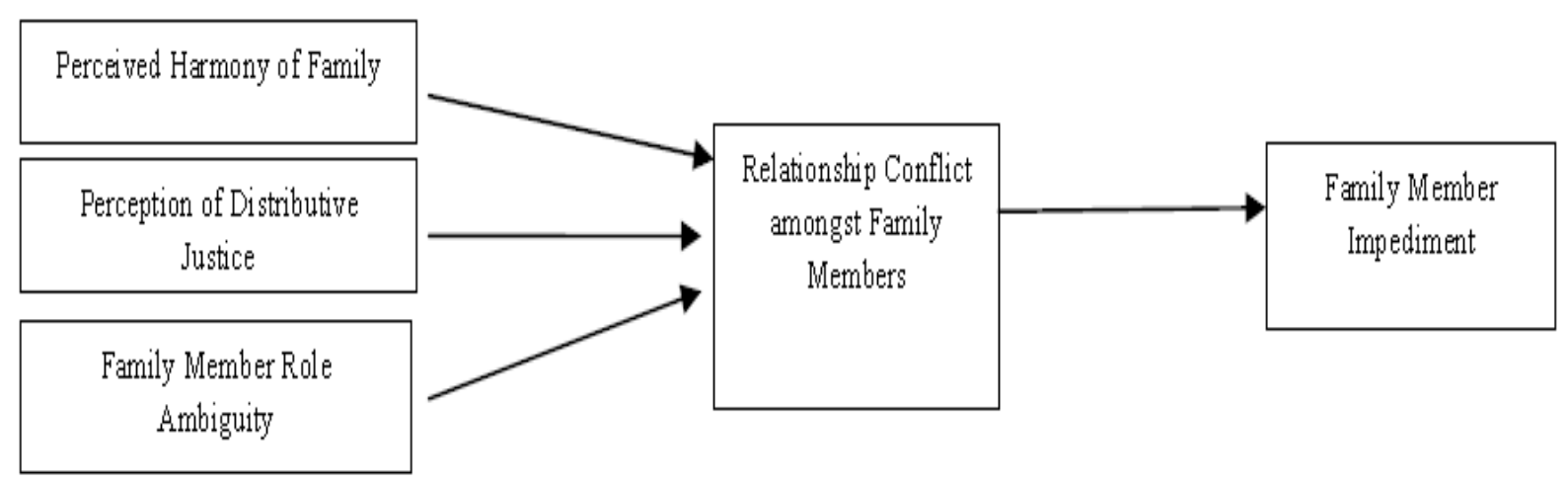

\subsection{Hypotheses}

1H1: Relationship conflict significantly mediates the relationship between harmony of family and family member impediment.

2H1: Relationship conflict significantly mediates the relationship between distributive justice and family member impediment.

3H1: Relationship conflict significantly mediates the relationship between role ambiguity and family member impediment.

\section{Methodology}

\subsection{Participants and Procedure}

The study is based on data obtained from a sample of 124 family firms in Modoko which is Furniture Store Site in Istanbul, Turkey. Modoko has become the leader in its sector which owns total of 350 companies. Modoko can carry out all the furniture needs of a home or office. (http://www.modoko.com.tr/ eng/modokohakkinda.asp, 07.01.2012).

According to descriptive statistics, the average number of employees that are work for those family firms are 24 . The mean score is 4 for the number of family members that work in our sample family businesses. 60 
percentages of the participants have close family relationship which means that core family work together.

The data collected by the researchers who visit the whole business firms personally. By this way the researchers could find a chance to talk with the problems of business firms in the furniture sector face to face. The data were collected by the researcher during January to March in 2013.

\subsection{Measures}

A number of scales employing five-point Likert type scales from 1 (Strongly Disagree) to 5 (Strongly Agree) were administered to measure the relationship between "family harmony norms", "distributive justice", "role ambiguity", "relationship conflict" and "family member impediment".

Dependent Variable: Family Member Impediment: This variable was measured by a scale developed by the Kidwell, Kellermanns \& Eddleston (2012). This scale consists of 7 items.

Independent Variables: Our study covers three independent variables.

Harmony of Family: This variable was measured by the scale developed by Beehr, Drexler \& Faulkner (1997) with 4 items.

Distributive Justice: This variable assessed with Moorman (1991) and Lee (2000) from the original relationship conflict scale by Price \& Mueller (1986). This measure is composed of 6 items.

Role Ambiguity: This variable was measured by 6 items which is developed by Rizzo, House \& Lirtzman (1970). The role ambiguity items are all reverse scored.

Mediator: Relationship Conflict: This variable was measured using the original relationship conflict scale by Jehn (1995). This measure consists of 4 items.

\subsection{Validity-Reliability}

In order to demonstrate the distinctiveness of family member impediment, harmony of family, distributive justice, role ambiguity, and relationship conflict from these constructs, we conducted a factor analysis of the items from these five scales separately. All of the items loaded strongly and distinctively on separate factors as in the original scale, without any exception which means no items were dropped from the subsequent analysis.

Table-1: Factor analysis results

\begin{tabular}{|c|c|c|c|}
\hline Variables & $\begin{array}{c}\text { Factor } \\
\text { Loadings }\end{array}$ & $\begin{array}{c}\text { Total } \\
\text { Variance } \\
\text { Explain(\%) }\end{array}$ & 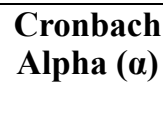 \\
\hline Distributive Justice (DJ) & & 0.73 & 0.92 \\
\hline DJ 2 & 0,90 & & \\
\hline DJ 6 & 0,87 & & \\
\hline DJ 1 & 0,87 & & \\
\hline D J 3 & 0,86 & & \\
\hline D J 4 & 0,83 & & \\
\hline D J 5 & 0,78 & & \\
\hline Family Member Impediment (FMI) & & 0.62 & 0.89 \\
\hline FMI 6 & 0,85 & & \\
\hline FMI 3 & 0,83 & & \\
\hline FMI 5 & 0,80 & & \\
\hline FMI 7 & 0,78 & & \\
\hline FMI 2 & 0,78 & & \\
\hline FMI 4 & 0,75 & & \\
\hline FMI 1 & 0,72 & 0.65 & 0.89 \\
\hline \multicolumn{4}{|l|}{ Role Ambiguity (RA) } \\
\hline RA 1 & 0,85 & & \\
\hline RA 2 & 0,85 & & \\
\hline RA 3 & 0,82 & & \\
\hline
\end{tabular}




\begin{tabular}{lccc}
\hline Variables & $\begin{array}{c}\text { Factor } \\
\text { Loadings }\end{array}$ & $\begin{array}{c}\text { Total } \\
\text { Variance } \\
\text { Explain(\%) }\end{array}$ & $\begin{array}{c}\text { Cronbach } \\
\text { Alpha (a) }\end{array}$ \\
\hline RA 6 & 0,78 & & \\
RA 5 & 0,77 & & \\
RA 4 & 0,74 & & 0.82 \\
Harmony of Family (HF) & & 0.65 & \\
HF 3 & 0,87 & & \\
HF 2 & 0,84 & & \\
HF 4 & 0,76 & & \\
HF 1 & 0,75 & & \\
Relationship Conflict (RC) & & 0.65 & \\
RC1 & 0,85 & & \\
RC 3 & 0,82 & & \\
RC 2 & 0,78 & & \\
RC 4 & 0,78 & & \\
\hline
\end{tabular}

As shown in Table 1, the factor loadings ranged from those intervals: distributive justice 0,90 to 0,78 ; family member impediment 0,85 to 0,72 ; role ambiguity 0,85 to 0,74 ; harmony of family 0,87 to 0,75 ; relationship conflict 0,85 to 0,78 which provided strong support for the convergent and discriminant validity of the measure. The pattern of reliability results for distributive justice 0,92 ; family member impediment 0,89 ; role ambiguity 0,89 ; harmony of family 0,82 ; relationship conflict 0,82 which show us the reliability of the scale is high.

\section{Results}

The mean, standard deviation and correlations results were given in Table 2.

Table-2: Descriptive statistics and correlations

\begin{tabular}{lllllll}
\hline Variables & Mean & SD & $\mathbf{1}$ & $\mathbf{2}$ & $\mathbf{3}$ & $\mathbf{4}$ \\
\hline 1.Family Harmony & 3,33 & 1,10 & & & & \\
2.Distributive Justice & 3,57 & 1,11 & $0,61^{* *}$ & & & \\
3.Role Ambiguity & 2,23 & 1,06 & $-0,53^{* *}$ & $-0,62^{* *}$ & & \\
4.Relationship Conflict & 2,33 & 1,20 & $-0,44^{* *}$ & $-0,58^{* *}$ & $0,50^{* *}$ & \\
5.Family Member Impediment & 2,40 & 1,25 & $-0,43^{* *}$ & $-0,48^{* *}$ & $0,54^{* *}$ & $0,60^{* *}$ \\
\hline
\end{tabular}

**Correlation is significant at the 0,01 level (2-tailed)

By looking Table 2 the mean scores of the variables it could be said that family harmony and distributive justice are exist. However, it could be asserted that role ambiguity, relationship conflict and family member impediment is moderately low in the furniture sector in Turkey.

Table-3: Hypotheses-1 steps regression analysis

Hypotheses 1-First Step Regression Analysis

\begin{tabular}{lccc}
\hline \multicolumn{1}{l}{ Dependent Variable: Family Member Impediment } & & \\
\hline Independent Variable: & $-0,429$ & $\mathbf{~ t}$ & $\mathbf{p}$ \\
Harmony of Family & $-5,248$ & 0,000 \\
$\mathbf{R}=0,429 ; \quad$ Adjusted $\mathbf{R}^{2}=0,178 ; \quad \mathbf{F}=27,545 ;$ & $\mathbf{p}=0,000$ & & \\
\hline Hypotheses 1-Second Step Regression Analysis & & \\
\hline Dependent Variable Relationship Conflict & & \\
\hline
\end{tabular}




\begin{tabular}{|c|c|c|c|c|}
\hline \multicolumn{2}{|c|}{ Independent Variable: } & \multicolumn{2}{|l|}{ Beta } & \multirow{3}{*}{$\begin{array}{c}\mathbf{p} \\
0,000\end{array}$} \\
\hline \multicolumn{2}{|c|}{ Harmony of Family } & \multicolumn{2}{|l|}{$-0,440$} & \\
\hline $\mathbf{R}=0,440$ & AdjustedR $^{2}=0,187$ & $\mathbf{F}=29,234$ & $\mathbf{p}=0,000$ & \\
\hline \multicolumn{5}{|c|}{ Hypotheses 1-Third Step Regression Analysis } \\
\hline \multicolumn{5}{|c|}{ Dependent Variable: Family Member Impediment } \\
\hline \multicolumn{2}{|c|}{ Independent Variable: } & Beta & $\mathbf{t}$ & $\mathbf{p}$ \\
\hline \multicolumn{2}{|c|}{ Harmony of Family } & $-0,207$ & $-2,616$ & 0,010 \\
\hline \multicolumn{2}{|c|}{ Relationship Conflict } & 0,506 & 6,406 & 0,000 \\
\hline $\mathbf{R}=0,625$ & Adjusted $\mathbf{R}^{2}=0,381$ & $\mathbf{F}=38813$ & $\mathbf{p}=0,000$ & \\
\hline
\end{tabular}

In order to test the mediation effect model (Baron\&Kenney 1986:1176) for 1H1; first, harmony of family was significantly related to the family member impediment, as proven also in Table 3. Second, harmony of the family was significantly related to the mediating variable which is role conflict as shown. Third, the dependent variable was related to the mediator, when controlling for the independent variable. Relation conflict was positively related to family member impediment. Forth, steps 1 and 2, multiple regressions analysis was used to test if there were a significant mediation by relationship conflict on the relation between harmony of family and family member impediment. The results showed that the effect of harmony of family on family member impediment, when controlling for relationship conflict is reduced ( $\beta$ for relationship conflict in step-3 which equals 0,207 is less than $\beta$ for relationship conflict in step- 1 which equals 0,429 ), then $1 \mathrm{H} 1$ is supported and relationship conflict is a partial mediator of the relationship between family member impediment and harmony of family.

Table-4: Hypotheses-2 steps regression analysis

Hypotheses 2-First Step Regression Analysis

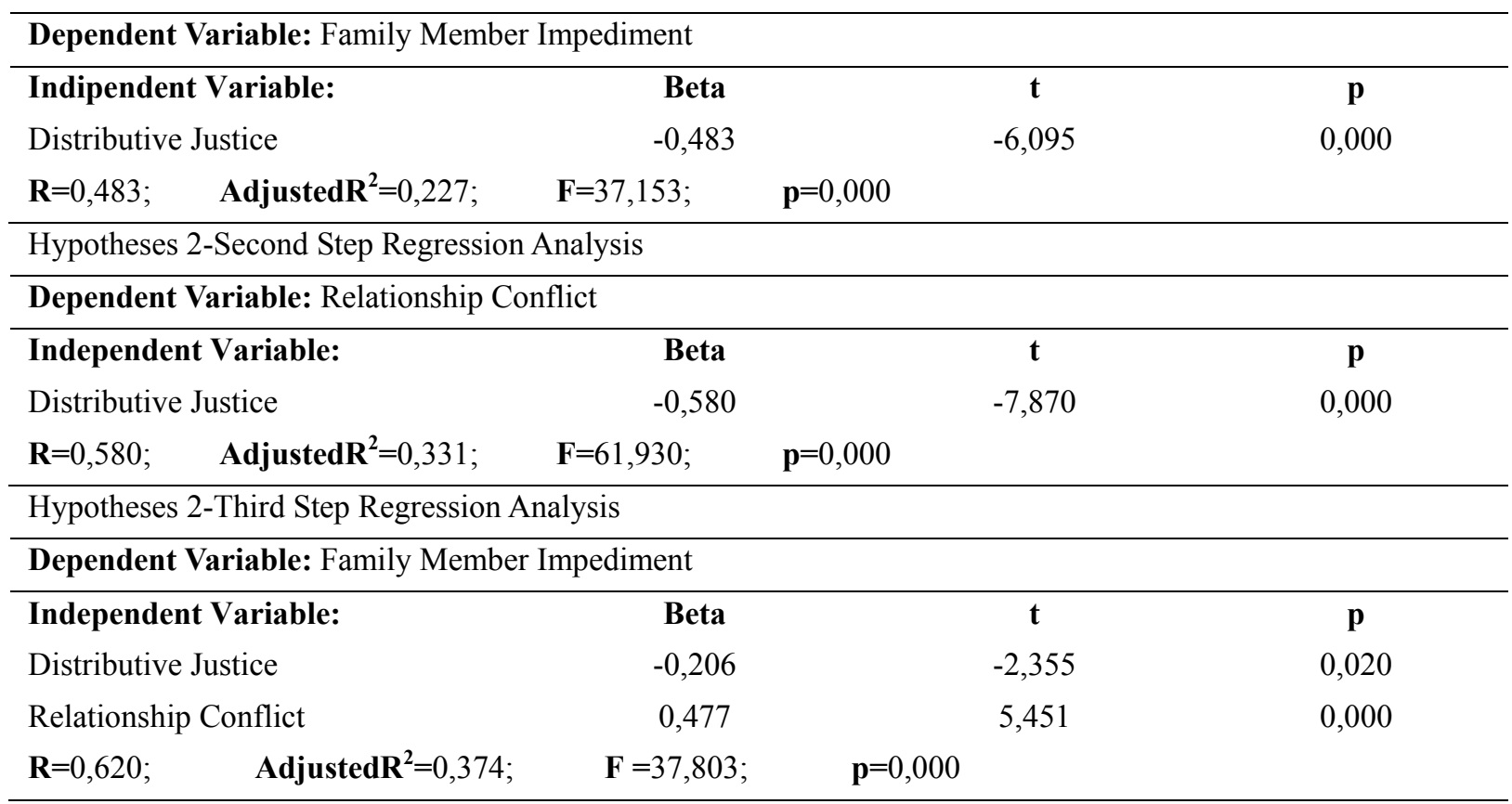

For testing the mediation model for $2 \mathrm{H} 1$; first, distributive justice was significantly related to family member impediment, as proven also in Table 4. Second, distributive justice was significantly related to the mediating variable, relationship conflict. Third, the dependent variable was related to the mediator, when controlling for the independent variable. In addition to steps 1 and 2, multiple regressions analysis was used to test if there were a significant mediation by relationship conflict on the relation between distributive justice and family member impediment. The results explained that the effect of distributive justice on family member impediment when controlling for relationship conflict is reduced ( $\beta$ for relationship conflict in step-3 which equals 0,206 is less 
than $\beta$ for relationship conflict in step- 1 which equals 0,483 ), then $2 \mathrm{H} 1$ is supported and relationship conflict is a partial mediator of the relationship between family member impediment and distributive justice.

Table-5: Hypotheses-3 steps regression analysis

Hypotheses 3-First Step Regression Analysis

\begin{tabular}{|c|c|c|c|}
\hline \multicolumn{4}{|c|}{ Dependent Variable: Family Member Impediment } \\
\hline Independent Variable: & Beta & $\mathbf{t}$ & $\mathbf{p}$ \\
\hline Role Ambiguity & 0,537 & 7,029 & 0,000 \\
\hline $\mathbf{R}=0,537 ; \quad$ Adjusted $\mathbf{R}^{2}=0,282$ & $\mathbf{F}=49,405$ & $\mathbf{p}=0,000$ & \\
\hline \multicolumn{4}{|c|}{ Hypotheses 3-Second Step Regression Analysis } \\
\hline \multicolumn{4}{|c|}{ Dependent Variable: Relationship Conflict } \\
\hline Independent Variable: & Beta & $\mathbf{t}$ & $\mathbf{p}$ \\
\hline Role Ambiguity & 0,502 & 6,411 & 0,000 \\
\hline $\mathbf{R}=0,502 ; \quad$ Adjusted $\mathbf{R}^{2}=0,246$ & $\mathbf{F}=41,098$ & $\mathbf{p}=0,000$ & \\
\hline \multicolumn{4}{|c|}{ Hypotheses 3-Third Step Regression Analysis } \\
\hline \multicolumn{4}{|c|}{ Dependent Variable: Family Member Impediment } \\
\hline Independent Variable: & Beta & t değeri & p değeri \\
\hline Role Ambiguity & 0,317 & 4,002 & 0,000 \\
\hline Relationship Conflict & 0,438 & 5,524 & 0,000 \\
\hline $\mathbf{R}=0,657 ; \quad$ Adjusted $\mathbf{R}^{2}=0,422$ & $\mathbf{F}=45,936$ & $\mathbf{p}=0,000$ & \\
\hline
\end{tabular}

To test the mediation model for $3 \mathrm{H} 1$; first, role ambiguity was significantly related to the family member impediment, as proven also in Table 5. Second, role ambiguity was significantly related to the mediating variable which is relationship conflict Third, the dependent variable was related to the mediator, when controlling for the independent variable. Fourth, steps 1 and 2, multiple regressions analysis was used to test if there were a significant mediation by relationship conflict on the relation between role ambiguity and family member impediment. The results showed the effect of role ambiguity on family member impediment, when controlling for relationship conflict, is reduced ( $\beta$ for relationship conflict in step-3 which equals 0,317 is less than $\beta$ for relationship conflict in step-1 which equals 0,537 ), then $3 \mathrm{H} 1$ is supported and relationship conflict is a partial mediator of the relationship between family member impediment and role ambiguity.

\section{Conclusion}

Reducing the likelihood of family member impediment might have vital importance for family firms. Harmony of the family, perceived distributive justice, role ambiguity is some of the factors that affect problems sourcing from family members in a family firm. In recent years, researches suggested negative relationships between harmony of family and family member impediment, and also between perceived distributive justice and family member impediment, and positive relationship between role ambiguity and family member impediment (Kidwell, Kellermanns \& Eddleston, 2012). In addition, relationship conflict has commonly been analyzed because of its effects on firm's basic fields of interests such as satisfaction, performance, knowledge sharing, commitment, intention to quit. Moreover, relationship conflict is dealt with as a full mediator in the relationship of harmony of the family, perceived distributive justice, role ambiguity and family member impediment.

One of the study results indicates the negative relationship between family harmony and family member's detriment, and also between perceived distributive justice and family member's detriment to firm. But on the contrary, role ambiguity is positively related to family member impediment. Higher rates in harmony of the family and perceived distributive justice are negative indicators; role ambiguity is positive indicator on family member issues in family firms. So achieving harmony, assuring justice and minimizing role ambiguity of family members are fundamental for keeping away from unethical attitudes of family members.

Other indicators of this study show that there is a negative relationship between harmony of family and relationship conflict, and also between distributive justice and relationship conflict. And also, there is a positive 
relationship between role ambiguity and relationship conflict. On the other hand, relation conflict is positively related to family member impediment.

Findings of this study state that harmony of family, perceived distributive justice, role ambiguity's effect on family member impediment is partially mediated by relationship conflict in family firms in furniture sector in Turkey. This result is compatible with Kidwell, Kellermanns \& Eddleston (2012)'s study that concluded the relationship conflict fully mediates those. Thus, mediating relationship occurs when a third variable plays an important role in governing the relationship between the independent and dependent variables (Baron \& Kenney, 1986). In the other words, relationship conflict serves partially to clarify the nature of the relationship between harmony of family, distributive justice, role ambiguity and family member impediment. Considering the mediating effect of relationship conflict, minimizing relationship conflict among family members could increase positive contribution of family members to the firm's success. In conclusion, providing harmony of family and distributing justice and clarifying role requirements could decrease the family member problems. In this context, it is important to manage a relationship conflict that has to be considered as a mediator by owners/managers in the family firms in order to struggle with family members' difficulties.

Our study suggests that in order to avoid family member issues family firms should create:

- An embracing cooperation and collaboration among family members.

- A robust family sprit that is also very important to lead to a common purpose, and to establish a sense of identification and commitment.

- Family harmony norms indicate synchronization and integration among family members that can also be indicated through family members.

- Fairness of how rewards and costs are shared by family members.

- A clear definition and understanding of family members' roles, functions, and responsibilities.

- Job descriptions which show individual's roles and responsibilities, and also help as a way to increase performance of family member.

- An environment in which minimized interpersonal tension, friction, annoyance, animosity, etc. among family members.

\section{Limitations and Directions for Future Research}

This study has a limitation that the research has been conducted in the family firms operating in the furniture sector located around Istanbul of Turkey. Because of that, the findings and outcomes of the study might not be valid for all of family firms located in other geographical areas and operated in different sectors. Other limitation of the study is related to the variables utilized that are independent of those such as harmony of family, distributive justice, role ambiguity, relationship conflict and dependent of family member impediment.

In order to have advanced research studies on family member issues in family firms, we suggest that more factors such as leadership styles, altruism and participative decision making process etc. could be included in research model in order to understand the other problematic variables causing family member impediment. From a practical perspective, future studies could consist of a wide range of sector sample to be able to make considerable suggestions to owner/managers of the family firms.

\section{Refrences}

Alpay, G., Muzaffer, B., Cengiz, Y., Saadet, Ç., \& Arikan, L. (2008). Performance Implications of Institutionalization Process in Family-Owned Businesses: Evidence from an Emerging Economy. Journal of World Business, 43(4), 435-448.

Altindag, E., Zehir, C., \& Acar, A. Z. (2011). Strategic Orientations and Their Effects on Firm Performance in Turkish Family Owned Firms. Eurasian Business Review, 1, 18-36.

Amundson, G. (1997). Harmony is Key to Effective Family Business Succession. Business First, Louisville, 14(2).

Ann, V. G. M., Shapiro, D. L., \& Brett, J. M. (2004). Can we Talk, and Should we? Managing Emotional Conflict in Multicultural Teams. Academy of Management Review, 29(4), 578-590.

Aquio, K. (1995). Relationships among Pay Inequity. Perceptions of Procedural Justice, and Organizational Citizenship. Employee Responsiblities and Rights Journal, 8(1), 21-33.

Arin, A., \& Ring, P. S. (2010). The Role of Fairness in Alliance Formation. Strategic Management Journal, 31, 
1054-1087.

Arnold, T. J., Landry, T. D., Scheer, L. K., \& Stan, S. (2009). The Role of Equity and Work Environment in The Formation of Salesperson Distributive Fairness Judgments. Journal of Personal Selling \& Sales Management, 29(1), 61-80.

Barney, J. B. (1986). Organizational Culture: Can It Be a Source of Sustained Competitive Advantage? The Academy of Management Review, 11(3), 656-665.

Baron, R. M., \& Kenney, D. A. (1986). The Moderator-Mediator Variable Distinction in Social Psychological Research: Conceptual, Strategic, and Statistical Considerations. Journal of Personality and Social Psychology, 51(6), 1173-1182.

Beard, F. (1996). Marketing Client Role Ambiguity as a Source of Dissatisfaction In Client-Ad Agency Relationships. Journal of Advertising Research, 9-20.

Beehr, T. A., Drexler Jr, J. A., \& Faulkner, S. (1997). Working in Small Family Business: Empirical Comparison to Non-family Business. Journal of Organizational Behavior, 18, 297-312.

Blodgett, J. C., Hill, D. J., \& Tax, S. S. (1997). The Effects of Distributive, Procedural, and Interctional Justice on Postcomplaint Behavior., Journal of Retailing, 73(2), 185-210.

Bobocel, D. R., Agar, S. E., Meyer, J. P., \& Irving, P. G. (1998). Managerial Accounts and Fairness Perceptions in Conflict Resolution: Differentiating the Effects of Minimizing Responsibility and Providing Justification. Basic and Applied Social Psychology, 20(2), 133-143.

Bolat, T., Bolat, O. İ., \& Yüksel, M. (2011). Relationship Between Role Ambiguity and Burnout: The Mediating Effect of Organizational Culture. Interdisciplinary Journal of Contemporary Research in Business, 2(10), 373-398.

Boles, J. S., Wood, J. A., \& Johnson, J. (2003). Interrelationships of Role Conflict, Role Ambiguity, and Work-Family Conflict with Different Facets of Job Satisfaction and The Moderating Effects Of Gender. Journal of Personal Selling \& Sales Management, 23(2), 99-113.

Burrus, J., \& Mattern, K. D. (2010). Equity, Egoism, and Egocentrism: The Formation of Distributive Justice Judgments. Basic and Applied Social Psychology, 32, 155-164.

Cavaliere, F. J., Mulvaney, T. P., \& Swerdlow, M. R. (2009). Global Poverty Act-A Teaching Lesson On Distributive Justice. Southern Journal of Business and Ethics, 1, 126-139.

Chen, Z. J. (2011). The Interactive Effects of Relationship Conflict, Reward, and Reputation on Knowledge Sharing. Social Behavior and Personality, 39(10), 1387-1394.

Chiu, C. M., Chiu, C. S., \& Chang, H. C. (2007). Examining The Integrated Influence of Fairness And Quality on Learners' Satisfaction And Web-Based Learning Continuance intention. Info Systems, 17, 271-287.

Chiua, C. M., Linb, H. Y., Sunc, S. Y., \& Hsu, M. H. (2009). Understanding Customers' Loyalty Intentions towards Online Shopping: An Integration of Technology Acceptance Model And Fairness Theory. Behaviour \& Information Technology, 28(4), 347-360.

Choi, J., \& Chen, C. C. (2004). Event and Entity Justice Perceptions: Distributive Justice and Compensation System Fairness in International Joint Ventures. Academy of Management, Best Conference Paper, 1-6.

Choi, K., \& Cho, B. (2011). Competing Hypotheses Analyses of the Associations between Group Task Conflict and Group Relationship Conflict. Journal of Organizational Behavior, 32, 1106-1126

Choil, J., \& Chen, C. C. (2007). The Relationships of Distributive Justice and Compensation System Fairness to Employee Attitudes in International Joint Ventures. Journal of Organizational Behavior, 28, 687-703.

Chonko, L. B. (1982). The Relationship of Span of Control to Sales Representatives' Experienced Role Conflict and Role Ambiguity. Academy of Management Journal, 25(2), 452-456.

Cropanzano, R., Slaughter, J. E., \& Bachiochi, P. D. (2005). Organizational Justice and Black Applicants' Reactions to Affirmative Action. Journal of Applied Psychology, 90(6), 1168-1184.

Curseu, P. L., Boros, S., \& Oerlemans, L. A. G. (2012). Task and Relationship Conflict in Short-term and Long-term Groups: The Critical Role of Emotion Regulation. International Journal of Conflict Management, 23(1), 97-107.

Davis, P. S., \& Harveston, P. D. (2001). The Phenomenon of Substantive Conflict in the Family Firm: A 
Cross-Generational Study. Journal of Small Business Management, 39(1), 14-30.

De Dreu, C. K. W., Van Dierendonck, D., \& De Best-Waldhober, M. (2002). Conflict at Work and Individual Well-being. In M. Schabracq, J. A. M. Winnubst, \& C. L. Cooper (Eds.), The Handbook of Work and Health Psychology (pp. 495-515). Chichester, UK: Wiley.

Deluga, R. J. (1989). Employee-Influence Strategies as Possible Stress-Coping Mechanisms for Role Conflict and Role Ambiguity. Basic and Applied Social Psychology, 10(4), 329-335.

Dierdorff, E. C., \& Rubin, R. S. (2007). Carelessness and Discriminability in Work Role Requirement Judgments: Influences of Role Ambiguity and Cognitive Complexity. Personnel Psychology, 60, 597-625.

Dijkstra, M. T. M., De Dreu, C. K. W., Evers, A., \& Dierendonck, D. (2009). Passive responses to interpersonal conflict at work amplify employee strain. European Journal of Work and Organizational Psychology, 18(4), 405-423.

Doherty, A., \& Hoye, R. (2011). Role Ambiguity and Volunteer Board Member Performance in Nonprofit Sport Organizations. Nonprofit Management \& Leadership, 22(1), 107-128.

Donnelley, R. (1964). The Family Business. Harvard Business Review, 42, 93-105.

Duarte, M., \& Davies, G. (2003) Testing the Conflict-Performance Assumption in Business-to-Business Relationships. Industrial Marketing Management, 32, 91-99.

Dyer, W. G. (2006). Examining the 'Family Effect' on Firm Performance. Family Business Review, 19(4), 253-273.

Eddleston, K. A., \& Kellermans, F. W. (2007). Destructive and productive family relationships: A Stewardship Theory Perspective. Journal of Business Venturing, 22, 545-565.

Erp, V., Kım, J. P. M., Giebels, E., Van Der Zee, K. I. \& Van Duijn, M. A. J. (2011). Expatriate Adjustment: The Role of Justice and Conflict in Intimate Relationships. Personal Relationships, 18, 58-78.

Fatima, G., \& Rehman, W. (2012). Impact of Role (Ambiguity and Conflict) on Teaching Assistants' Satisfaction and Intention to Leave: Pakistani HEIs. International Journal of Business and Management, 7(16), 56-61.

Fields, D, Pang, M., \& Chiu, C. (2000). Distributive and Procedural Justice as Predictors of Employee Outcomes in Hong Kong. Journal of Organizational Behavior, 21, 547-562.

Fletcher, D. (2009). The Role of Family Start Ups in the Emergence of a Small Business Sector in Bulgaria. Journal of Enterprising Culture, 17(3), 351-375.

Fletcher, D., Helienek, E., \& Zafirova, Z. (2009). The Role Of Family Start Ups in The Emergence of a Small Business Sector in Bulgaria. Journal of Enterprising Culture, 17(3), 351-375.

Fryxel, G. E. (1992). Perceptions of Justice Afforded by Formal Grievance Systems as Predictors of a Belief in a Just Workplace. Journal of Business Ethics, 11, 635-647.

Gail, W., \& Mamen, K. (2002). Examning Justice and Conflict between Mining Companies and Indigeneous Peoples: Cerro Colorada and the Ngabe- Bugle in Panama. Journal of Business and Management, 8(3), 293-329.

Ghorpade, J., Lackritz, J., \& Singh, G. (2011). Personality as a Moderator of the Relationship between Role Conflict, Role Ambiguity, and Burnout. Journal of Applied Social Psychology, 41(6), 1275-1298.

GregBon, T., Wendell, J., \& Aono, J. (1994). Role Ambiguity, Role Conflict, and Perceived Environmental Uncertainty: Are the Scales Measuring Separate Constructs for Accountants? Behavioral Research in Accounting, 6, 144-159.

Haara, J. M., \& Spell, C. S. (2009). How Does Distributive Justice Affect Work Attitudes? The Moderating Effects of Autonomy. The International Journal of Human Resource Management, 20(8), 1827-1842.

Hamilton, R. W. (2006). When the Means Justify the Ends: Effects of Observability on the Procedural Fairness and Distributive Fairness of Resource Allocations. Journal of Behavioral Decision Making, 9, 303-320.

Haque, A., \& Aslam, M. S. (2011). The Influence of Distributive Justice on Organizational Citizenship Behaviors: Mediating Role of Emotional Exhaustion and Organizational Attachment. International Journal of Business and Social Science, 2(15), 155-165.

Harris, J. D. (2009). What's Wrong with Executive Compensation? Journal of Business Ethics, 85, 147-156.

Harvey, S., \& Haines III, V. Y. (2005). Employer Treatment of Employees during A Community Crisis: The Role 
of Procedural and Distributive Justice. Journal of Business and Psychology, 20(1), 53-68.

Hofer, A. R., Knemeyer, A. M., \& Murphy, P. R. (2012). The Roles of Procedural and Distributive Justice in Logistics Outsourcing Relationships. Journal of Business Logistics, 3(3), 196-209.

Hornung, S., Glaser, J., \& Rouseau, D. M. (2010). Interdependence as an I(-) Deal: Enhancing Job Autonomy and Distributive Justice via Individual Negotiation. German Journal of Research in Human Resource Management, 24(2), 108-129.

Huang, J. C. (2010). Unbundling Task Conflict and Relationship Conflict: The Moderating Role of Team Goal Orientation and Conflict Management. International Journal of Conflict Management, 21(3), 334-355.

Huang, J. C. (2012). The Relationship Between Conflict and Team Performance in Taiwan: The Moderating Effect of Goal Orientation. The International Journal of Human Resource Management, 23(10), 2126-2143.

Ismail, K. M., Richard, O. C., \& Taylor, E. C. (2012). Relationship Conflict in Supervisor-Subordinate Dyads: A Subordinate Perspective. International Journal of Conflict Management, 23(2), 192 -218.

Janss, R., Rispens, S., Segers, M., \& Jehn, K. A. (2012). What is Happening Under the Surface? Power, Conflict and the Performance of Medical Teams. Medical Education, 46, 838-849.

Jehn, K. A. (1995). A Multi-method Examination of the Benefits and Detriments of Intragroup Conflict. Administrative Science Quarterly, 40, 256-282.

Jehn, K. A., \& Mannix, E. A. (2001). The Dynamic Nature of Conflict: a Longitudinal Study of Intragroup Conflict and Group Performance. Academy of Management Journal, 4(2), 238-251.

Johnson, S. K., Holladay, C. L., \& Miguel, A. (2009). Quinones, Organizational Citizenship Behavior in Performance Evaluations: Distributive Justice or Injustice? Journal of Business Psychology, 24, 409-418.

Judeh, M. (2011). Role Ambiguity and Role Conflict as Mediators of the Relationship Between Orientation and Organizational Commitment. International Business Research, 4(3), 171-181.

Judge, T. A., \& Colquitt, J. A. (2004). Organizational Justice and Stress: The Mediating Role of Work-Family Conflict. Journal of Applied Psychology, 89(3), 395-404.

Judge, T. A., Colquitt, J. A., Ghorpade, J., Lackritz, J., \& Singh, G. (2011). Personality as a Moderator of the Relationship between Role Conflict, Role Ambiguity, and Burnout. Journal of Applied Social Psychology, 41(6), 1275-1298.

Kalbers, L. P., \& Cenker, W. J. (2008). The Impact of Exercised Responsibility, Experience, Autonomy, and Role Ambiguity on Job Performance in Public Accounting. Journal of Managerial Issues, 20(3), 327-347.

Kashyap, V., Ribeiro, Á. H. P., Asare, A., \& Brashear, T. G. (2007). Developing Sales Force Relationalism: The Role of Distributive And Procedural Justice. Journal of Personal Selling \& Sales Management, 27(3), 235-245.

Kellermanns, F. W., \& Eddleston, K. A. (2007). A family perspective on when conflict benefits family firm performance. Journal of Business Research, 60, 1048-1057.

Kets de Vries, M. F. R. (1993). The Dynamics of Family Controlled Firms: The Good and the Bad News. Organizational Dynamics, $21(3), 59-71$.

Kidwell, R. E., Kellermanns, F. W., \& Eddleston, K. A. (2012). Harmony, Justice, Confusion, and Conflict in Family Firms: Implications for Ethical Climate and the "Fredo Effect". Journal of Business Ethics, 106, 503-517.

Kumar, N., Scheer, L. K., \& Steenkamp, J. B. E. M. (1995). The Effects of Supplier Fairness on Vulnerable Resellers. Journal of Marketing Research, 32, 54-65.

Kwon, S., Min Soo, K I M, Kang, S. C., \& Kim, M. U. (2008). Employee Reactions to Gainsharing Under Seniority Pay Systems: The Mediating Effect Of Distributive, Procedural, And Interactional Justice. Human Resource Management, 47(4), 757-775.

Lau, R. S., \& Cobb, A. T. (2010). Understanding the Connections Between Relationship Conflict and Performance: The intervening roles of trust and Exchange. Journal of Organizational Behavior, 31, 898-917.

Lee, H. R. (2000). An Empirical Study of Organizational Justice as a Mediator of the Relationships among Leader-Member Exchange and Job Satisfaction, Organizational Commitment, and Turnover Intentions in 
the Lodging Industry. Doctorial Dissertation.

Lee, J. (2006). Impact of Family Relationships on Attitudes of the Second Generation in Family. Business, Family Business Review, 19(3), 175-191.

Li, F., Zhou, F., \& Leung, K. (2011). Effects of Task and Relationship Conflicts on Individual Workbehaviors. International Journal of Conflict Management, 22(2), 131-150.

Li, F., Zhou, F., \& Leung, K. (2011). Expecting the Worst: Moderating Effects of Social Cynicism on the Relationships Between Relationship Conflict and Negative Affective Reactions. Journal Business Psycology, 26, 339-345.

Litzky, B. E., Eddleston, K. A., \& Kidder, D. L. (2006, February). The Good, the Bad, and the Misguided: How Managers Inadvertently Encourage Deviant Behaviors. Academy of Management Perspectives, 91-103.

Martínez-Moreno, E., González-Navarro, P., Zornoza, A., \& Ripoll, P. (2009). Relationship, Task and Process Conflicts on Team Performance: The Moderating Role of Communication Media. International Journal of Conflict Management, 20(3), 251-268.

Miller, D., Breton-Miller, I. L., \& Scholnick, B. (2008). Stewardship vs. Stagnation: An Empirical Comparison of Small Family and Non-Family Businesses. Journal of Management Studies, 45(1), $51-78$.

Mills, H., \& Schulz, J. (2009). Exploring the Relationship between Task Conflict, Relationship Conflict, Organizational Commitment. Sport Management International Journal, 5(1), 5-18.

Moorman, R. H. (1991). Relationship Between Organizational Justice and Organizational Citizenship Behaviors: Do Fairness Perceptions Influence Employee Citizenship? Journal of Applied Psychology, 76(6), 845-855.

Netemeyer, R. G., Johnston, M. W., \& Burton, S. (1990). Analysis of Role Conflict and Role Ambiguity in a Structural Equations Framework. Journal of Applied Psychology, 75(2), 148-157.

Olson, P. D., Zuiker, V. S., Danes, S. M., Stafford, K. H., Ramona, K. Z., \& Duncan, K. A. (2003). The Impact of the Family and the Business on Family Business Sustainability. Journal of Business Venturing, 18(5), 639-666.

Onyemah, V. (2008). Role Ambiguity, Role Conflict, and Performance: Empirical Ev idence of an Inverted-U Relationship. Journal of Personal Selling \& Sales Management, 28(3), 299-313.

Othman, R. (2008). Organisational Politics: The Role of Justice, Trust and Job Ambiguity. Singapore Management Review, 30(1), 43-53.

Pandey, S. K., \& Wright, B. E. (2006). Connecting the Dots in Public Management: Political Environment, Organizational Goal Ambiguity, and the Public Manager's Role Ambiguity. Journal of Public Administration Research and Theory, 1, 511-532.

Parayitam, S., Olson, B. J., \& Bao, Y. J. (2010). Task Conflict, Relationship Conflict and Agreement-Seeking Behavior in Chinese Top Management Teams. International Journal of Conflict Management, 21(1), 94-116.

Pearce, J. L. (1981). Bringing Some Clarity to Role Ambiguity Research. Academy of Management Review, 6(4), 665-674.

Pelled, L. H. (1996, November-December). Demographic Diversity, Conflict, and Work Group Outcomes: An Intervening Process Theory. Organization Science, 7(6), 615-631.

Pelled, L. H., Eisenhardt, K. M., \& Xin, K. R. (1999). Exploring the Black Box: An Analysis of Work Group Diversity, Conflict, and Performance. Administrative Science Quarterly, 44, 1-28.

Peterson, M. F., \& Smith, P. B. (1995). Role Conflict, Ambiguity, and Overload: A 21-Nation Study. Academy of Management Journal, 38(2), 429-452.

Ram, N., Khoso, I., Shah, A. A., Abdul, S., \& Chandio, F. R. (2011). Role Conflict and Role Ambiguity as Factors in Work Stress among Managers: A Case Study of Manufacturing Sector in Pakistan. Asian Social Science, 7(2), 113-118.

Rizzo, J. R., House, R. J., \& Lirtzman, S. I. (1970). Role Conflict and Ambiguity in Complex Organizations. Administrative Science Quarterly, 15(2), 150-163.

Sakires, J., Dohert, A., \& Misener, K. (2009). Role Ambiguity in Voluntary Sport Organizations. Journal of Sport Management, 23, 615-643. 
Singh, J. (1993). Boundary Role Ambiguity: Facets, Determinants, and Impacts. Journal of Marketing, 57, 11-31.

Thiagarajan, P, Chakrabarty, S., Lueg, J. E., \& Taylor, R. D. (2007). Work-Family Role Strain of Single Parents: The Effects of Role Conflict and Role Ambiguity. The Marketing Management Journal, 17(1), 82-94.

Tidd, S. T., Mclntyre, H. H., \& Friedman, R. A. (2004). The Importance of Role Ambiguity And Trust In Conflict Perception: Unpacking The Task Conflict to Relationship Conflict Linkage. The International Journal of Conflict Management, 15(4), 364-380.

Ussahawanitchakit, P. (2008). Building Job Satisfaction of Certified Public Accountants (Cpas) in Thailand: Effects Of Role Stress Through Role Conflict, Role Ambiguity, And Role Overload,. Journal of Academy of Business And Economics, 8(2), 12-22.

Wall, K. L., \& Preston, J. C. (2010). Action Research in the Development of a Chinese Family Enterprise. Organization Development Journal, 28(4), 77-90.

Wall, K. L., \& Preston, J. C. (2010). Action Research in the Development of a Chinese Family Enterprise. Organization Development Journal, 28(4), 77-90.

Wilson, J. M., \& Hunt, C. S. (2009). Summary Brief the Influence of Sales Engineers on Salesperson Time Management, Role Ambiguity, and Information Effectiveness. Society for Marketing Advances Proceedings, 251-252. 